\title{
关于中国土壤碳库及固碳潜力研究的若干问题
}

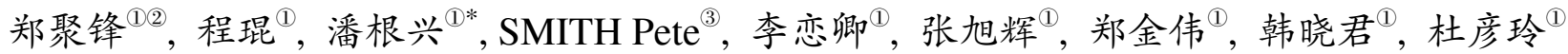 \\ (1) 南京农业大学农业资源与生态环境研究所, 农业与气候变化研究中心, 南京 210095; \\ (2) 南京林业大学资源环境学院, 南京 210037; \\ (3) Institute of Biological and Environmental Sciences, School of Biological Sciences, University of Aberdeen, 23 St Machar Drive, Aberdeen, \\ AB24 3UU, UK \\ * 联系人, E-mail: gxpan@njau.edu.cn
}

2011-04-09 收稿, 2011-07-14 接受

国家自然科学基金国际合作重大项目(407100190002)和教育部基础研究重大项目资助

\begin{abstract}
摘要 土壤碳库研究及碳汇问题是近年来土壤碳循环与全球变化研究的热点领域. 本文回顾 了中国土壤碳库估算的研究成果, 分析了我国土壤碳库在气候变化下的演变态势, 并探讨了 土壤有机碳矿化与温室气体的释放问题. 整合已有的研究资料, 可以认为中国土壤总有机碳 库接近 $90 \mathrm{Pg}$, 无机碳库约为 $60 \mathrm{Pg}$, 农田土壤已有的固碳速率在 $20 \sim 25 \mathrm{Tg} / \mathrm{a}$ 水平. 农田土壤 固碳的理论容量可以达到 $2.0 \mathrm{Pg}$ 水平, 但农业技术的实施能够实现的技术潜力可能仅为理论 潜力的 $1 / 3$ 左右. 因此, 改善土壤管理和农田经营机制可能是提高土壤固碳技术潜力的关键. 土壤固碳中有机碳积累并不表现出分解的敏感性, 固碳显得有利于提高农田生产力和改善生 态系统功能, 一些农田综合温室气体排放的生命周期评价的案例研究反而显示有机质积累下 农业生产的碳排放强度没有提高甚而降低. 未来中国土壤碳库研究的重点发展方向在于: (1) 以流域为尺度和地球表层系统为对象的系统固碳与碳汇研究; (2) 生态系统土壤碳固定与稳 定机制, 特别是土壤固碳与生产力和生态服务功能的协同机理和多界面过程. 中国土壤碳科 学将面临多学科集成和多目标服务的新发展机遇.
\end{abstract}

关键词

土壤碳库

土壤固碳

有机碳稳定性

温室气体排放

土壤碳科学
当前, 随着联合国政府间气候变化专门委员会 (IPCC)第四次评估报告正式提交, 以全球变暖为主 要表现的全球气候急剧变化及其与不断增加的大气 温室气体的关系已经被接受为无可争议的事实, 切 实减少温室气体排放、增加碳汇成为缓解气候变化的 首要任务(UNFCC, Fact Sheet The Need for mitigation. http://unfccc.int/press/items/2794 php.2008) ${ }^{[1]}$. 世界土 壤(在 $1 \mathrm{~m}$ 深度内)有机碳库储量约达 $1500 \mathrm{Pg}$, 另含 有超过 $1000 \mathrm{Pg}$ 的无机碳库 ${ }^{[2]}$, 在全球陆地碳循环与 气候变化中具有关键影响.

我国陆地面积广大, 生态系统类型丰富, 其中森 林面积约为 $1.42 \times 10^{6} \mathrm{~km}^{2}$ (含表土有机碳 $5.9 \mathrm{Pg}$ ), 草 地 $3.31 \times 10^{6} \mathrm{~km}^{2}$ (含表土有机碳 $1.15 \mathrm{Pg}$ ) ${ }^{[3]}$, 农田 $1.30 \times$
$10^{6} \mathrm{~km}^{2}$ (含表土有机碳 $5 \mathrm{Pg}$ ), 湿地为 $0.38 \times 10^{6} \mathrm{~km}^{2}$ $(0.9 \mathrm{Pg} \text { 或 } 1 / 10 \text { 总碳库 })^{[4]}$. 由于快速扩展的城市化和 工业化过程、过度放牧等人类活动异常突出, 我国 $\mathrm{CO}_{2}$ 等温室气体排放不断增加, 成为目前世界上最大 $\mathrm{CO}_{2}$ 工业排放源之一. 随着联合国气候变化框架条约 缔约国制定的《京都议定书》的执行, 如何促进陆地 生态系统碳的固定及其稳定, 减少温室气体来抵消 部分工业排放，成为我国乃至国际社会普遍关注的 重大环境问题，这对于缓解因温室气体带来的气候 变化的负效应具有重要意义.

关于我国土壤碳库计量、温室气体释放问题的研 究已有较多报道, 本文回顾和概述了近年来我国碳 库计量(包括无机碳库)进展及问题, 分析讨论土壤有

英文版见: Zheng J F, Cheng K, Pan G X, et al. Perspectives on studies on soil carbon stocks and the carbon sequestration potential of China. Chinese Sci Bull, 2011, 56, doi: 10.1007/s11434-011-4693-7 
机碳动态、土壤有机碳稳定与温室气体释放的关系, 进一步提出了未来研究展望, 期望为土壤碳库与土 壤固碳研究提供参考.

\section{1 中国土壤碳库计量研究进展}

欧美等主要国家在 20 世纪 90 年代初完成了土壤 碳库估计和全球土壤碳库总值估计, 我国土壤碳库 的估计也一直是我国碳循环研究领域科学家的一项 重要研究内容. 20 世纪 90 年代中期以来, 中国学者 开始关注和研究土壤碳库及其变化问题. 生态学家 方精云等人 ${ }^{[5]}$ 对全部土壤均一化为 $1 \mathrm{~m}$ 厚度, 初步估 算提出中国土壤有机碳储量高达 $185 \mathrm{Pg}$. 潘根兴 ${ }^{[6]}$ 首 次采用《中国土种志》1 6 卷 ${ }^{[7]}$ 中全部约 2500 个土种 的有机碳含量进行加权平均法估算, 得到 $1 \mathrm{~m}$ 深有机 碳储量为 $50 \mathrm{Pg}$. 随后, 不同学科研究者采用第二次 全国土壤普查资料和生态系统植被土壤碳库分配模 型, 以不同比例尺的植被图和土壤图为面积依据进 行了多种估计的探索. 王绍强等人 ${ }^{[8,9]}$ 分别采用我国 第一次土壤普查资料和第二次全国土壤普查资料, 并根据 1:400 万中国土壤图的土壤面积估算得到中 国土壤总有机碳库分别为 100 和 $92 \mathrm{Pg} . \mathrm{Wu}$ 等人 ${ }^{[10]}$ 采用第二次全国土壤普查资料，根据其建立的土壤 有机碳与容重的关系改进了碳密度估算方法, 统计 方法估算得出我国总有机碳库约为 $70.3 \mathrm{Pg}$. 稍后, Yang 等人 ${ }^{[11]}$ 鉴于第二次土壤普查中西北地区调查样 点普遍缺乏, 增加了对西北特别是青藏高原区的补 充路线调查数据(增加 810 个剖面), 并基于新建立的 数据库中有机碳-容重关系和有机碳密度的土壤剖面 深度变化关系, 估算了全国土壤有机碳库为 $69.1 \mathrm{Pg}$. 几乎同时, $\mathrm{Li}$ 等人 ${ }^{[12]}$ 采用中国科学院土壤资源数据 资料(包含 2456 个土壤剖面, 8714 个土壤诊断层)进行 $1 \mathrm{~m}$ 深土壤有机碳密度统计分析, 估算得到全国土壤 总有机碳库 $88.3 \mathrm{Pg}$. 中国科学院南京土壤研究所史 学正课题组 ${ }^{[13,14}$ 利用其构建的中国土壤信息系统数 据库和编制的 1:100万土壤图, 将全部图斑的土壤类 型有机碳数据和与土壤图链接, 进而提出全国土壤 总有机碳库 $89.1 \mathrm{Pg}$ 的估计值. 在第 236 次香山会议 上, 与会土壤学家讨论认为中国土壤总有机碳库应 在 70 90 Pg 范围, 提出可以将 $90 \mathrm{Pg}$ 作为中国土壤总 有机碳库的默认值 ${ }^{[15]}$.

可以看出, 尽管国内各位专家学者在我国土壤 总有机碳库估算结果上日渐趋近，但估计值尚存在
很大的不确定性, 这些不同估计值的差异来自数据 资料的代表性、空间分辨率和尺度扩张时的有机碳变 化趋势的不一致性. 除了较早的研究基本上是采用 生态系统类型平均值法 ${ }^{[5]}$ 和土壤类型平均值法 ${ }^{[6]}$, 2003年以来的各种碳库研究的资料和方法的差异是 这种不确定性的来源. 提供有机碳密度统计的剖面 样本数可能是关键的因素, 2003 年以后的研究采用 的剖面数也均在 2000 个以上, 新近的估计研究还采 用了诊断层和土壤属性数据 ${ }^{[12,13]}$. 用于计算的中国 土壤面积数据也是差异的主要原因, 早期研究的面 积数据一般采用土壤普查的报道数据, 2007 年以后 的研究报道均采用土壤图解译面积. Yang 等人 ${ }^{[11]}$ 采 用的土壤面积数据是 $8.8037 \times 10^{6} \mathrm{~km}^{2}, \mathrm{Yu}$ 等人 ${ }^{[13]}$ 根据 $1: 100$ 万土壤图得到的土壤面积数据为 $9.281 \times 10^{6} \mathrm{~km}^{2}$, 其碳库估计值大于 Yang 等人 ${ }^{[11]}$ 估计值达 $20 \mathrm{Pg}$. 用 于估计全部土壤有机碳密度的容重数据和土壤剖面 深度值也是一个不可忽视的因素. 在大多数估计中, 土壤剖面默认深度 $1 \mathrm{~m}$, 事实上许多山区土壤剖面深 度达不到 $1 \mathrm{~m}$, 特别是在青藏高原 ${ }^{[11]}$. 尽管如此, 这 些研究中剖面平均有机碳密度的估计值差异幅度 (70 96 tC/ $\left./ \mathrm{hm}^{2}\right)$ 远远小于总碳库估计值的差异幅度.

有关无机碳库估算, 目前的研究资料还相对缺 乏，潘根兴等人 ${ }^{[6,16]}$ 根据《中国土种志》中 2500 个土 壤剖面计算得出我国土壤无机碳库为 $60 \mathrm{Pg}, \mathrm{Wu}$ 等人 ${ }^{[17]}$ 根据中国第二次土壤普查资料估算值约为 $55.3 \mathrm{Pg}$, 与 潘根兴发表的 $60 \mathrm{Pg}$ 估算结果接近; $\mathrm{Li}$ 等人 ${ }^{[12]}$ 采用 中国土壤资源调查数据估算值 $(1 \mathrm{~m})$ 为 $77.9 \mathrm{Pg}$, 明显 高于前两者的报道值(表 1). 从目前的研究结果看, 无机碳库估算值明显小于有机碳库. 同时, 估算结果 仍然存在较大的不确定性.

无机碳库的更新时间更长, 作为碳储存形式对 于减少大气 $\mathrm{CO}_{2}$ 浓度的长期效应不可忽视. 土壤有 机碳分解产生的 $\mathrm{CO}_{2}$ 通过反应: $\mathrm{SOC}-\mathrm{CO}_{2}$ (气态 $\mathrm{g}$ )$\mathrm{CO}_{2}(\mathrm{aq})-\mathrm{HCO}_{3}$-(aq) $-\mathrm{CaCO}_{3}$ (s), 可以有一部分土壤 $\mathrm{CO}_{2}$ 最终转化为重新沉淀的碳酸盐碳, 增加土壤次生

\section{表 1 中国土壤无机碳库估计研究比较}

\begin{tabular}{|c|c|c|}
\hline 估计值 $(\mathrm{Pg})$ & 估计方法 & 文献 \\
\hline 0.0 & $\begin{array}{l}\text { 中国土种志 } 2500 \text { 种土种, 以土壤厚度加权的 } \\
\text { 平均无机碳含量 }\end{array}$ & {$[6,16]$} \\
\hline 55.3 & 第二次土壤普查资料, 34411 个剖面统计分析 & [17] \\
\hline 77.9 & $\begin{array}{l}\text { 中国土壤资源数据库 } 2456 \text { 个剖面, } 8714 \text { 个土 } \\
\text { 壤诊断层统计分析 }\end{array}$ & [12] \\
\hline
\end{tabular}


碳酸盐和 SIC 的含量 ${ }^{[18]}$. 最近几年来, 我国学者试图 探讨有机碳与无机碳的转化关系. 潘根兴 ${ }^{[19]}$ 曾经提 出用土壤微形态研究法研究成土碳酸盐, 观察显微 镜下形成的碳酸盐物象, 从而分析该物像所涉及的 形成机理、探讨形成该物象时的外界环境和气候等因 素状况, 定性研究土壤有机起源碳向土壤发生性碳 酸盐的转移. 陈骏等人 ${ }^{[20]}$ 用 $\mathrm{Sr}$ 同位素研究陕西洛川 黄土剖面中的土壤碳酸盐, 根据 ${ }^{87} \mathrm{Sr} /{ }^{86} \mathrm{Sr}$ 比值的不同, 对该土壤的原生和次生碳酸盐进行区分. 有些研究 者试图从土壤有机碳与无机碳的相对含量的变化去 探讨两者的关系. 耿元波等人 ${ }^{[21]}$ 对内蒙古锡林河流 域温带草原的不同土地利用方式下的土壤碳转移规 律进行探讨表明, 贝加尔针茅草原开星为农田使 $1 \mathrm{~m}$ 土层内的有机碳含量降低, 而土壤无机碳含量升高, 且钻积化位置变浅; 放牧在使草原表层土壤有机碳 含量减少、深层有机碳含量增加的同时, 也减少了无 机碳的含量. 曾骏等人 ${ }^{[22]}$ 对甘肃灌漠土 18 年定位试 验研究得出, 土壤有机碳与无机碳在 $0 \sim 50 \mathrm{~cm}$ 剖面分 布上呈相反规律, 而且施肥对两者的影响也正好相 反, 有机-无机肥料配施和单施有机肥明显增加耕层 有机碳含量, 而降低无机碳含量, 单施化肥对两者均 无显著影响; 相似地, 黄斌等人 ${ }^{[23]}$ 在华北潮土 20 年 的定位试验中得出, $\mathrm{N}$ 和 $\mathrm{P}$ 配施有机肥可增加 $0 \sim 1 \mathrm{~m}$ 土层中有机碳含量, 而无机碳储量变化随有机碳增 加而降低. 然而, 目前关于有机-无机碳转移的机制 问题尚缺乏足够的研究资料.

\section{2 土地利用变化与土壤碳库演变}

\section{1 土壤碳库的历史演变}

土壤碳库的历史变化表明, 人为利用下土壤碳 库变化对已发生的全球变化有规模性影响 ${ }^{[24,25]}$, 国 外对土壤碳库的历史变化研究十分重视, 采用时空 尺度转换和生态系统模型对全球和区域的土壤碳库 变化作过估计 ${ }^{[26]}$. 目前一般认为, 人类活动下全球 土壤碳库的总消减达到土壤原碳库的 $5 \%$ 左右 ${ }^{[27]}$, IPCC 估计全球土壤碳库的历史损失量为 $55 \mathrm{Pg}^{[28]}$. 国外科学家对我国土壤碳库的历史变化问题甚为关 注, $\mathrm{Lal}^{[27]}$ 提出我国土壤碳库的最近时期损失为 $3.5 \mathrm{Pg}$ (包括沙漠化的 $2 \mathrm{Pg}$ ), Lindert 等人 ${ }^{[29]}$ 根据我国农业历 史资料和 1960 年前文献的土壤资料提出我国广大地 区土壤存在土壤碳库严重损失; 而李长生 ${ }^{[30]}$ 根据模
型计算结果提出我国 1950 年以来土壤碳库存在持续 消减, 1970 年以来这种损失达到 $70 \mathrm{Tg}$ 的规模, 这些 资料虽然没有足够实测资料和模型研究资料予以对 比, 但已在国际全球变化研究领域产生重要影响. $\mathrm{Wu}$ 等人 ${ }^{[10]}$ 通过第二次全国土壤普查资料中自然土 壤和耕种土壤的有机碳资料的统计对比, 估计我国 人为利用下土壤碳库演变的规模, 认为我国自然土 壤开垦为耕地后的总有机碳库损失为 7 8 Pg, 这主 要发生在东北和其他半干旱半湿润地区. 他同时指 出, 我国仍然有较大面积的农业土壤碳库与自然土 壤相比没有变化, 而灌溉土壤的碳库表现为增加. Song 等人 ${ }^{[31]}$ 采用第二次土壤普查中详尽的耕层有机 碳资料, 分别统计估计不同地区和不同土壤类型的 自然和耕种土壤有机碳密度, 对比揭示出耕作导致 我国表土有机碳密度平均下降了 $(14.8 \pm 15.1) \mathrm{t} / \mathrm{hm}^{2}$, 所产生的碳库历史损失总量仅约为 $2 \mathrm{Pg}$, 指出这种 损失在华北、西北和西南地区达到 $60 \%$ 以上. 这与全 球变化的区域响应和生态环境脆弱性的梯度相吻合. 另外, 碳损失可能主要发生在生态系统严重退化的 地区, 例如西南石灰岩山地丘陵区 ${ }^{[32]}$, 土壤侵蚀严 重的地区 ${ }^{[33]}$. 碳损失也发生在湿地开辱地区，仅我国 湿地土壤大面积开垦引起的有机碳损失估计 $1.5 \mathrm{Pg}^{[4]}$. 我国农业耕作土壤在高强度集约化利用和高化学投 人下的有机碳库损失一方面可能是目前我国耕作土 壤普遍有机质含量较低的原因, 另一方面可能对全 球土壤的有机碳损失与向大气的 $\mathrm{CO}_{2}$ 释放有重要的 影响.

\section{2 我国土地利用下的碳库动态与碳汇效应}

(i ) 湿地退化与土壤碳库损失。据“湿地国 际”2007 年的资料, 全球湿地土壤总面积约占陆地面 积的 $6 \%$ (http://www.wetlands.org/articlemenu.aspx?id= ae774022-0c1a-4293-a107-a73225128e75). 全球湿地 土壤的总碳库为 $550 \mathrm{Pg}$, 占全球陆地土壤碳库的 $1 / 3$, 相当于大气碳库和植被碳库的一半. 湿地土壤碳库 在全球气候变化以及人为利用干扰下变化剧烈. 全 球湿地土壤的 $\mathrm{CO}_{2}$ 温室气体排放已经相当于全球总 排放的 1/10 (http: //unfccc.int/files/meetings/cop_13/ application/pdf/cmp_guid_cdm.pdf). 历史上湿地围层 是造成土壤有机碳损失的一个重要原因, 据估计, 我 国 1950 年以来湖泊湿地围层面积在 $1.30 \times 10^{6} \mathrm{hm}^{2[34]}$, 三江平原的围垦更多地发生在最近 $30 \mathrm{a}^{[35]}$, 不同地 
区和不同类型的湿地围垦后有机碳的变化不同. 三 江平原和诺尔盖的沼泽湿地机碳损失可高达原含量 的 80\% 90\%，这种损失表现为湿地开丕后温室气体 排放的增加, 为湿地由汇转变为碳源的观察事实所 证实 ${ }^{[36]}$. 而在长江中下游的湖泊湿地，围怎后有机 碳的降低幅度在 $30 \%$ 以下，王树起等人 ${ }^{[37]}$ 和陆琦等 人 ${ }^{[38]}$ 对不同土地利用方式下三江平原湿地土壤碳变 化的研究也可以看到, 湿地开垦为稻田比开垦为旱 地有机碳的损失小. 刘子刚等人 ${ }^{[39]}$ 估计近 $50 \mathrm{a}$ 来三 江平原湿地有机碳的总损失量可达 $215 \mathrm{Tg}$. 根据上 述湿土壤平均有机碳密度资料和全国耕地土壤有机 碳平均密度资料, 由已开垦的湿地面积可概略估计 近 $50 \mathrm{a}$ 来全国因围是造成的湿地表土有机碳损失量 可能达 $1.5 \mathrm{Pg}^{[4]}$, 这相当于 2006 年我国总 $\mathrm{CO}_{2}$ 排放 量 ${ }^{[40]}$, 这个问题在我国温室气体减排工作中值得 重视.

（ii）农业利用下农田碳库演变. 科学界公认表 土对全球变化和人为干扰最为敏感, 全球表土(0 $30 \mathrm{~cm}$ )总有机碳库为 $684 \mathrm{Pg}^{[41]}$, 如果扣除两极冰盖 面积, 则全球平均表土碳密度达 $47.8 \mathrm{t} / \mathrm{hm}^{2}$. 按 $\mathrm{Smith}^{[42]}$ 提供的资料, 欧盟自然土壤碳密度平均为 $70.8 \mathrm{t} / \mathrm{hm}^{2}$, 农业利用土壤平均为 $53.0 \mathrm{t} / \mathrm{hm}^{2}$. 根据 Song 等人 ${ }^{[31]}$ 统计估算表明, 我国自然土壤表土有机 碳密度为 $(50 \pm 47) \mathrm{t} / \mathrm{hm}^{2}$, 而耕作土壤平均仅为 $(35 \pm$ 32) $\mathrm{t} / \mathrm{hm}^{2}$, 水田 ${ }^{[43]}$ 和旱地分别为 $(46.9 \pm 25.7) \mathrm{t} / \mathrm{hm}^{2}$ 和

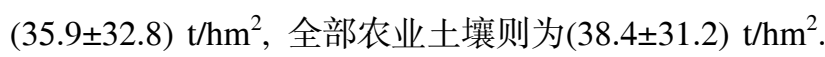
许信旺等人 ${ }^{[44]}$ 通过收集我国 1980 2006 年以来 966 个样点农田耕层土壤有机碳的实测数据, 统计分析 表明: 土地利用方式对土壤固碳差异明显, 水稻土有 机碳水平明显高于旱地, 水田耕层有机碳含量为旱 地耕层有机碳含量的 $175 \%$ 176\%, 从土壤有机碳的 增幅来看, 菜地土壤有机碳平均年增幅达 $2.88 \pm 3.4 \%$, 高于水田和旱地的增幅. 侯鹏程等人 ${ }^{[45]}$ 采用耕地质 量监测资料分析了江苏省吴江市 6 种土地利用方式 下的土壤有机碳含量的变化, 结果表明在稻田、林 地、桑园、菜地、果园、旱地 6 种常见的土地利用方 式中, 稻田的有机碳含量、碳密度最大, 从 1982 年第 二次土壤普查到 2003 年的 20 多年中, 只有稻田土壤 有机碳呈增长趋势, 表明稻田是一种固碳能力很强 的土地利用方式. 李志鹏等人 ${ }^{[46]}$ 利用稳定性同位素 技术对太湖地区一个水稻田改种玉米 3 年的土壤有 机碳变化显示, 水田转变成旱地后耕层土壤有机碳
分解加速, 碳储量快速减少. 导致土地利用方式差异 的一个原因是土地管理政策, 在 20 世纪 70 年代, 由 于联产承包责任制政策的实施，以家庭为单位的土 地经营机制正式形成，并由此导致的土地破碎化利 用在目前我国政策不变的条件下仍将继续维持 ${ }^{[47]}$. 土地利用的破碎化与土地利用强度差异对土壤质量 及作物产量的影响已有研究 ${ }^{[48,49]}$, 最近土地破碎化 利用所引起土壤有机碳差异受到国际土壤学家的关 注 $^{[50]}$. Feng 等人 ${ }^{[51]}$ 在江西红壤区选择了一个村级单 位，并以农户为对象进行研究发现，不同农户经营管 理下土壤表层有机碳含量存在较大差异, 其范围介 于 $1.72 \sim 25.2 \mathrm{~g} / \mathrm{kg}$ 之间, 并因田块利用的破碎程度(田 块的利用面积范围介于 $0.007 \sim 0.630 \mathrm{hm}^{2}$ 之间)与家庭 经营管理模式而异. 在田块尺度上, $<0.1 \mathrm{hm}^{2}$ 的田块 土壤有机碳含量比 $\geqslant 0.1 \mathrm{hm}^{2}$ 低 $20 \%$, 旱田比稻田低 $70 \%$, 自主经营的田块有机碳含量几乎是被出租的 2 倍; 另外, 施用绿肥和种植三季稻可分别增加土壤有 机碳 30\%和 55\%, 显然, 增加农田土壤碳库必须在增 进作物管理水平的同时兼顾农户经营的管理.

（iii）农田土壤碳库动态整体趋势. 尽管全球土 壤碳库储量巨大 $(1500 \mathrm{Pg}$ 的有机碳和约 $1000 \mathrm{Pg}$ 的无 机碳), 但在全球陆地生态系统碳库中, 只有农业土 壤碳库是受到强烈人为干扰且在较短的时间尺度上 可以调节的碳库 ${ }^{[52]}$, 因而, 全球农业土壤碳库储量 及其固碳能力被认为是评估近期温室气体减排潜力 的重要依据. 近年来我国学者对于不同土地利用下 有机碳变化的研究十分活跃, 焦点是：(1) 土壤固碳 的存在规模; (2) 不同利用下的动态及其全球变化效 应; (3) 数据资源的开发, 模型的应用, 定量估计方 法的创新等问题, 以及区域尺度的调查及资料的发 掘, 评价农田土壤动态. 尽管历史上我国农业经营和 生产下土壤碳库损失对环境产生了一定的负效应, 例如在西北生态脆弱区风沙化、区域干旱化、盐渍化 的快速扩张化以及高强度农业利用的消耗，导致了 土壤有机碳的严重损失. 但最近的文献报道, 包括江 苏太湖平原县域尺度 ${ }^{[53]}$ 、江西红壤丘陵自然村农田

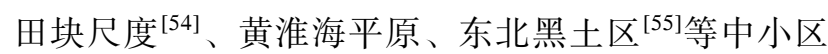
域尺度的有机碳水平的调查和统计，均显示出我国 农田有机碳变化呈总体增加态势.

长期试验资料的挖掘和进一步的模型模拟深刻 表征了农田土壤有机碳动态变化. 王伯仁等人 ${ }^{[56]}$ 报 道的江西红壤丘陵区旱作 13 年定位试验(有机-无机 
配施)、陈安否等人 ${ }^{[57]}$ 发表的中国科学院桃源农业生 态试验站 15 年稻田定位施肥试验结果, 周萍等人 ${ }^{[58]}$ 对江苏吴江 17 年不同施肥定位试验的研究(长江中下 游平原地区), Huang 等人 ${ }^{[59]}$ 报道的四川盆地紫色土 区(重庆) 16 年不同耕作的定位试验, 以及孟磊等人 ${ }^{[60]}$ 在黄淮海平原潮土区 16 年不同施肥试验区进行的研 究, 均显示在配方施肥和有机、无机配合施肥条件以 及良好的农作制下农田土壤有机碳呈普遍的上升趋 势, 因而中国农业土壤表现出明显的固碳实效(表2),

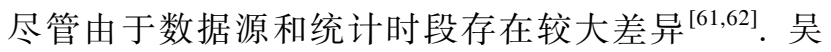
乐知等人 ${ }^{[63]}$ 通过对全国不同区域 26 个长期试验站点 29 个长期试验的农田土壤有机碳变化情况的统计研 究表明, 在平衡施肥和有机、无机复合施肥下农田表 土有机碳含量每年增加 $0.05 \sim 0.29 \mathrm{~g} / \mathrm{kg}$, 估计在良好 施肥下过去 20 a 农田表土有机碳固定量为 $0.2 ~ 1.6$ Pg. 黄耀和孙文娟 ${ }^{[64]}$ 分析了我国 1993 年以来关于区域耕 地土壤有机碳变化的 200 余篇文献中近 60000 个土壤 样品的测定结果后, 发现近 $20 \mathrm{a}$ 来占 53\% 60\%的耕 地面积的土壤有机碳含量呈增长趋势, 而 30\% 35\% 呈下降趋势, 4\% 6\%基本持平. 这种趋势在不同的地 理气候区存在差异. 在此基础上, 他们估计近 $20 \mathrm{a}$ 来 中国农田土壤表土有机碳储量增加了 300 400 Tg. 而 Sun 等人 ${ }^{[65]}$ 通过对收集 146 篇公开发表的文献资 料的分析得出, 我国农田有机碳固定主要发生在华 东和东北地区, 在 1980 2000 年间平均固碳速率为 $21.9 \mathrm{Tg} / \mathrm{a}$, 总固碳量为 $437 \mathrm{Tg}$; Pan 等人 ${ }^{[66]}$ 最近收集 了文献上有效的基本覆盖全国土壤有机碳监测数据 1099 个, 统计分析了不同时期和不同区域的土壤有 机碳动态. 虽然有机碳增减的趋势及区域分布与黄 耀等人 ${ }^{[64]}$ 的研究结果大致相同, 但计算表明, 1982 2006 年全国农田土壤有机碳平均年增长幅度达 $(0.69 \pm 1.86) \%$. 在区域格局上表现为华北、华东、西 北增长明显, 而西南、华南和东北地区增长不明显. 根据不同区域和不同土地利用下的平均增长速率, 估计全国农田表土 $(0 \sim 20 \mathrm{~cm})$ 有机碳库年均增加 $(24.1 \pm 15.8) \sim(27.1 \pm 21.9) \mathrm{Tg}$, 近 $25 \mathrm{a}$ 来的累计增加值 达 $(0.58 \pm 0.38) \sim 0.65 \pm 0.53)$ Pg. 表 2 的文献资料的研 究结果可以认为, 中国农田土壤固碳速率在20 25 Tg/a 范围. 进一步分析我国农田有机碳增加的原因是: (1) 主导因素是秸秆还田, 这比其他因素更有利于农田 土壤有机碳咜量的增加; (2) 化肥对于促进农田土壤 碳库增加具有明显作用; (3) 农田中较丰富的有效氮
素营养对输人有机质转化为土壤腐殖质是十分有 利的.

(iv) 农田土壤固碳容量及实现的农业技术限制. 在全球陆地生态系统碳库中只有农业土壤碳库是强 烈人为干扰而又可以在较短的时间尺度上可以调节 的碳库. 据估计, 全球农业土壤固碳潜力为 $20 \mathrm{Pg}$, 在最近 25 年内其速率平均可达 $(0.9 \pm 0.3) \mathrm{Pg} / \mathrm{a}^{[2]}$. 国 外科学家对我国土壤固碳潜力甚为关注, $\mathrm{Lal}^{[27]}$ 认为 2050 年前中国土壤固碳总潜力为 $11 \mathrm{Pg}$, 其中有机碳 固定潜力为 $105 \sim 198 \mathrm{Tg} / \mathrm{a}$, 无机碳为 7 138 Tg/a. Sun 等人 ${ }^{[65]}$ 利用文献报道资料分析认为, 在良好的农田 管理措施下我国农田未来(到 2050 年)固碳潜力 2 2.5 Pg C. 李忠佩 ${ }^{[67]}$ 从农田有机质平衡的实验资料的粗 略估算认为, 我国低产农田碳库增加的规模为 $500 \mathrm{Tg}$.

可以从各种途径初步估计中国农田表土土壤固 碳的理论潜力或生物物理潜力. 根据 Song 等人 ${ }^{[31]}$ 的 估计, 农业土壤有机碳因为耕作的历史损失为 $2 \mathrm{Pg}$, 如果这种损失可以恢复, 则理论上固碳潜力可达 2 $\mathrm{Pg}$; 根据许信旺 ${ }^{[68]}$ 对于 1982 2006 年间农田表土有 机碳动态的定量统计中有机碳增量与观测起始值的 关系, 估计出中国农田土壤的未来固碳潜力可能达 2 $\mathrm{Pg}$ (其中稻田 $(0.8 \pm 0.2) \mathrm{Pg}$, 而旱地为 $(1.2 \pm 0.5) \mathrm{Pg}$ ). 另 外, 假设秸秆还田的保护性耕作是固定和稳定农田 土壤有机碳的最优方式, 则根据王成已等人 ${ }^{[69]}$ 的耕 作与有机碳关系的定量统计资料, 当前土壤有机碳 水平与秸秆还田的保护性耕作下土壤有机碳的平均 值间的差距可以认为是农田土壤固碳理论饱和限. 采用有机碳变化与初始有机碳含量的关系(图 1) ${ }^{[70]}$, 假设每年 $0.1 \mathrm{~g} / \mathrm{kg}$ 的变化为可观察监测限, 则稻田表 土有机碳的理论饱和含量为 $30 \mathrm{~g} / \mathrm{kg}$, 旱地为 $15 \mathrm{~g} / \mathrm{kg}$. 按照 Pan 等人 ${ }^{[6]}$ 报道的农田有机碳当前水平值, 则 估算稻田和旱地表土有机碳固定的理论潜力分别为 0.91 和 $1.01 \mathrm{Pg}$. 这里的结果可以初步认为, 中国农

表 2 我国农田土壤固碳速率的部分文献报道

\begin{tabular}{ccc}
\hline 固碳速率 $(\mathrm{Tg} / \mathrm{a})$ & 观测年限 & 文献 \\
\hline 23.6 & $1996 \sim 2006$ & {$[61]$} \\
7.9 & $1990 \sim 2000$ & {$[62]$} \\
21.9 & $1980 \sim 2000$ & {$[65]$} \\
$15 \sim 20$ & $1993 \sim 2006$ & {$[64]$} \\
24.9 & $1985 \sim 2006$ & {$[63]$} \\
$24.1 \sim 27.1$ & $1980 \sim 2006$ & {$[66]$} \\
\hline
\end{tabular}




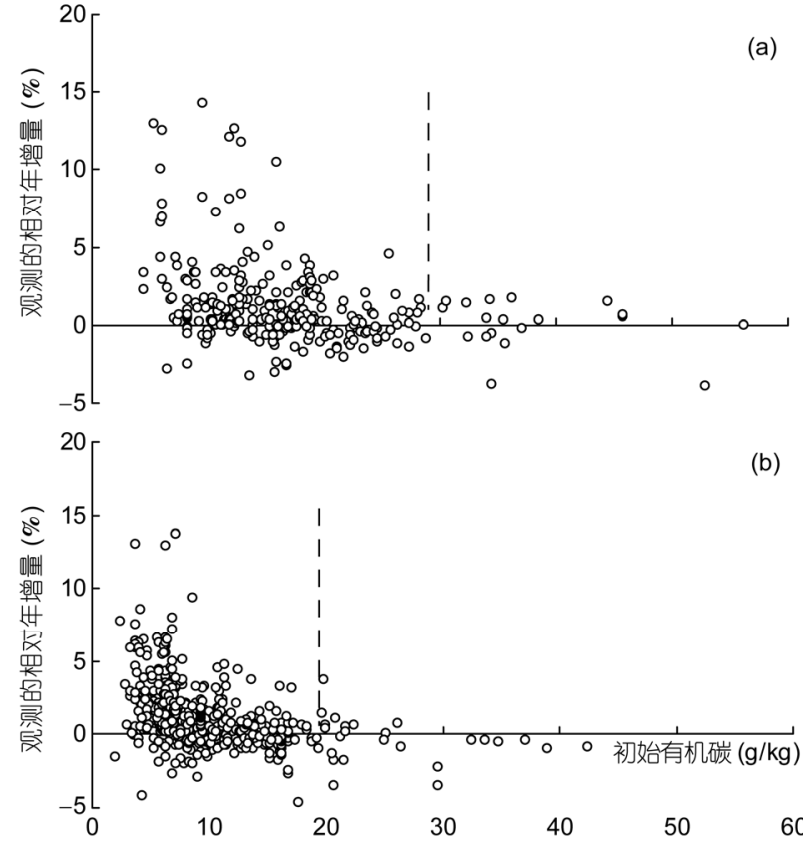

图 1 土壤监测中有机碳增量变化与初始有机碳含量的关系 (a) 稻田; (b) 旱地. 数据引自文献[70]

田土壤的表土理论固碳容量在 $2 \mathrm{Pg}$ 水平, 与 $\mathrm{Lal}^{[27]}$ 根据生态恢复而估算的中国土壤总固碳潜力为 $11 \mathrm{Pg}$, 农田土壤固碳潜力也为 $2 \mathrm{Pg}$ 的结果相当.

农田土壤固碳在我国温室气体减排中占有重要 地位. 估算的农田土壤固碳潜力占我国土壤总固碳 潜力的 $20 \%$. 最近 25 a 来增加的农田土壤碳汇相当 于我国 2006 年总 $\mathrm{CO}_{2}$ 排放量的约 $40 \%$, 如果按 1994 年排放水平计算, 则农田土壤碳固定可以贡献 $20 \%$ 的减排份额. 而美国和欧盟的土壤碳固定仅可以起 到其同时期减排份额的 5\% 7\% ${ }^{[71,72]}$. 根据 Liao 等 人 ${ }^{[73]}$ 最近的估计, 江苏省表土在 1982 2004年有机碳 库增加了 $24 \mathrm{Tg}$, 相当于该省 1994 年总 $\mathrm{CO}_{2}$ 排放的 $20 \%$. 这一结果与 IPCC 第四次评估报告中农业土壤 最大可以起到 $20 \%$ 的全球 $\mathrm{CO}_{2}$ 排放当量的减排份额 的结论相呼应 ${ }^{[74]}$. 同时, 对长期试验下稻田土壤有 机碳积累下温室气体释放变化 ${ }^{[75,76]}$, 生态系统净碳 平衡变化 ${ }^{[77,78]}$, 生态系统土壤动物 ${ }^{[79]}$ 、微生物多样性 变化 ${ }^{[80,81]}$, 农田杂草多样性 ${ }^{[82]}$, 有机污染物降解能 力 ${ }^{[83]}$ 以及氮素利用率和水稻产量的变化 ${ }^{[84,85]}$ 等的一 些列研究还证明农田土壤固碳, 特别是稻田土壤固 碳还可以起高产稳产和增汇的共赢作用 ${ }^{[86]}$. 因此, 农业发展中的土壤固碳效应在我国农业应对气候变 化中的作用应予充分肯定 ${ }^{[87]}$.
上述研究的固碳潜力属于自然过程决定的容量, 其实现的程度取决于农业技术的普遍推广性. 实际 上, 许多管理和技术因素将限制这种理论潜力的完 全实现, 在一定技术经济条件下可以实现的土壤固 碳容量一般称之为技术潜力. 例如, 配方施肥下土壤 固碳速率可能是常规施肥下的 2 倍以上, 结合秸秆还 田的保护性耕作下土壤固碳速率可以达到非保护性 耕作的数倍. 但是, Pan 等人 ${ }^{[66]}$ 报道的 1982 2006 年 间农田土壤固碳平均速率仍明显低于配方施肥下的 土壤固碳速率, 25 年来的总固碳量估计为 $0.6 \mathrm{Pg}$, 不 及理论潜力的 $1 / 3$. 根据王成已等人 ${ }^{[69]}$ 的研究, 不采 用秸秆还田的少免耕固碳效应不显著, 而结合秸秆 还田的保护性耕作是目前为止固碳速率最高的耕作 管理途径. 但是, 截至 2007 年底, 我国保护性耕作应 用面积为 3000 多万亩 (1 亩 $=6.667 \times 10^{-4} \mathrm{hm}^{2}$, 余同), 不到全部农田的 $2 \%$. 根据农业部的规划, 到 2015 年, 保护性耕作总推广面积将达到 2 亿亩, 约占全部耕地 面积的 10\%(www.gov.cn/gzdt/2009-08/28/content_140367. $\mathrm{html})^{[88]}$. 而至 2008 年底, 全国测土配方施肥实施面 积为 9 亿亩, 2010 年的计划实施面积为 11 亿亩, 约占 全部耕地的 $60 \%$ 左右(http://chinalnn.com/Html/Article/ Class21/Class24/24_212667.html) ${ }^{[89]}$. 因此, 促进土壤 固碳的农业管理技术的推广覆盖程度仍是实现农田 土壤固碳潜力的主要限制. 另外, 我国农业生产的经 营管理机制也是制约农田土壤固碳技术潜力的重要 因素. 根据 Feng 等人 ${ }^{[51]}$ 对江西农户农田经营的调查, 小规模农户 $\left(<0.1 \mathrm{hm}^{2}\right)$ 和转包耕地不合理使用下土壤 碳密度仅相当于较大规模农户 $\left(>0.1 \mathrm{hm}^{2}\right)$ 和承包地良 好利用下农田的 $1 / 3$. 改善土地管理和经济机制, 扩 大土地流转和规模良好经营, 也是提高农田土壤固 碳技术的主要途径.

\section{3 土壤碳库稳定性与全球变化}

\section{1 土壤新碳积累的稳定性与温室气体释放}

土壤新碳积累的稳定性是指环境条件改变下有 机碳的易分解性, 直接关系到固定碳是否在环境变 化下成为新的温室气体排放源. 目前国内关于土壤 稳定性研究主要是围绕环境污染(例如 N 沉降和土壤 酸化 $)^{[90]}$ 和全球变暖下土壤有机碳分解和温室气体释 放的研究 ${ }^{[11,92]}$.

农田有机碳稳定性主要受农田措施的影响, 包 括耕作、施肥、灌溉排水等, 而土壤有机碳积累中碳 
库 ${ }^{[93]}$, 特别是动力学碳库分配及其对气候变化的响 应与反馈效应还存在很多不确定性，特别是在有机 质组分的化学结构及其生物学矿化潜力与温室气体 释放潜力的关系的认识上有不一致的结果 ${ }^{[94]}$. 新近, 有研究报道提出农田有机碳分解受土壤有机质的化 学组成及稳定性控制微生物呼吸分解和酶活性的控 制 ${ }^{[95]}$. 最近, Kemmitt 等人 ${ }^{[95]}$ 研究认为, 土壤本土有 机质矿化不受土壤微生物生物量及其活性与区系组 成的影响; 同理, Fang 等人 ${ }^{[96]}$ 发现土壤有机碳中不同 组分 (活性组分和难降解组分)对外界温度的响应也 不存在差异. Vanhala 等人 ${ }^{[97]}$ 研究不同玉米种植历史 的农田土壤有机碳的矿化, 表明是老碳更灵敏地响 应于升温下的微生物分解; 反之, Rinna 等人 ${ }^{[98]}$ 应用 土壤芯的田间长期培养方法, 研究了添加秸秆对土 壤微生物及有机碳矿化的影响, 表明升温下土壤微 生物生长明显得到促进, 土壤中 $\mathrm{DOC} / \mathrm{DON}$ 的比率明 显升高. 他们认为, 微生物活性是全球变化中影响碳 平衡的重要控制因素. 我们对吴江一个长期肥料试 验田研究表明, 长期施用化肥影响土壤有机碳的结 构芳香性降低, 不利于有机碳稳定 ${ }^{[99]}$. 张逸飞等 人 ${ }^{[100]}$ 注意到不同施肥长期试验下微生物功能群和酶 活性功能在不同施肥处理间的差异, 提出功能群和 酶活性的差异可能是不同施肥生产力和土壤肥力质 量的表征指标. 我们曾经研究了一个红壤性水稻土 长期不同施肥下土壤的好气和厌气培养下的矿化, 发现厌气培养下土壤有机碳矿化率显著低于好气条 件, 且两种条件下土壤有机碳矿化率对温度敏感性 的影响因素不同, 好气条件下 $\mathrm{Q}_{10}$ 与游离氧化铁显著 相关, 而在淹水条件下则与微生物熵呈显著相关, 这 提示稻田土壤土著微生物功能群对厌气条件的适应 性 ${ }^{[101]}$. 因此, 新碳积累是否会因微生物分解的起爆 效应而提高土壤有机质矿化而增加温室气体释放, 至今没有一致的认识, 这因采用实验室土壤培养还 是根际系统的培养而异 ${ }^{[102 ~ 104]}$, 以及因野外的长期试 验还是实验室的短期培养而异 ${ }^{[104,105]}$.

\section{2 土壤固碳与温室气体释放}

一般地, 有机碳增加会提高土壤异氧呼吸, 从而 可能增加土壤温室气体排放. 湿地土壤的研究中, 很 多报道过湿地土壤排水或开垦后呼吸释放强烈升 高 ${ }^{[36,106]}$. 最近, 我们观察到湖泊湿地的有机碳矿化 潜力数倍于其开垦后数十年的稻田, 湿地土壤排水
后土壤呼吸强烈而产生很高的 $\mathrm{CO}_{2}$ 通量 ${ }^{[107]}$, 这可能 是我们观察到长江中下游湿地土壤在开垦 10 年内有 机碳快速损失 ${ }^{[108,109]}$ 的原因.

一些实验室培养研究表明, 不同发生类型稻田 土壤培养下土壤好气呼吸与有机碳矿化速率和升温 敏感性低于森林土壤和旱地 ${ }^{[91]}$. 尽管土壤中 $N$ 素水 平常常是影响土壤呼吸的最活跃因子 ${ }^{[91,110]}$, 但稻田 土壤有机碳水平(因而全 $\mathrm{N}$ 水平也可能较高)与呼吸 矿化并不成线性关系, 不同施肥下有机碳矿化速率 反而是积累有机碳少的土壤中高, 有机-无机配合施 肥不但促进了碳积累, 而且降低了土壤呼吸与排放

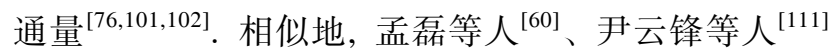
对华北平原潮土施有机肥与不施有机肥相比, 旱地 土壤有机碳含量提高而呼吸活性降低. 太湖地区长 期定位试验表明，不同肥料施用下，有机-无机配合 施肥下有机碳积累, 反而降低了微生物的代谢熵而 降低了单位有机碳的温室气体释放 ${ }^{[75,76]}$. 最近对南 方几个肥料长期试验土壤呼吸和微生物区系的研究 显示, 配合施肥下土壤呼吸率降低, 伴随着土壤微生 物区系向真菌优势方向演替 ${ }^{[112]}$, 而真菌的碳代谢率 显著低于细菌. 与这个研究相互支撑的是, Zou等 人 ${ }^{[113]}$ 报道了南方某地不同施肥下连续 3 年的温室气 体监测，化肥配合施用下，有机碳含量高于化肥区， 而土壤温室气体释放强度(综合温室气体释放强度) 显著低于化肥施用下.

近 2 年来, 对于多地不同长期施肥处理下土壤有 机碳和碳平衡的研究, 认识到有机无机配合施肥下 有机碳明显积累, 有利于系统明显提高净碳汇效应. 李洁静等人 ${ }^{[114,115]}$ 在分别对太湖地区和江西红壤区 2 个长期定位试验田(太湖地区 20 年; 江西红壤区 24 年)进行资料收集整理基础上，评估了碳汇收益，表 明太湖地区有机无机肥配施的净碳汇量是单施化肥 的 3 倍, 其经济效益是单施化肥下的 1.1 倍; 而在红 壤区有机无机肥配施下的土壤净碳汇量比单施化肥 高 50\%. 彭华等人 ${ }^{[116]}$ 以农业部望城红壤水稻土长期 定位肥力效应试验稻田为对象，通过收集历年作物 产量、调落物固碳和农田 $\mathrm{CO}_{2}$ 排放等观测资料及生态 系统的物质和管理投人等资料, 估算年碳汇平衡和 经济收益, 发现增施有机肥 (猪粪、稻草)的处理 $(\mathrm{NPK}+\mathrm{RS}, \mathrm{NK}+\mathrm{PM}$ 和 $\mathrm{NP}+\mathrm{RS})$ 的碳汇量分别是相应 的仅施化肥处理(NPK, NK 和 NP)的 1.1, 1.7 和 1.4 倍. 有机肥配施的经济效益是单施化肥的 1.1 1.6 倍, 这 
与李洁静等人 ${ }^{[115]}$ 在红壤区的研究结果相似. 同时也 表明, 有机无机配施处理比单施化肥具有更高的生 态系统生产力和更高的碳汇效应和经济收益, 这一 点并没有因区域差异而改变, 进一步表明有机无机配 施是促进土壤固碳减排的一项关键的农田管理措施.

尽管一些研究提出, 稻田土壤有机碳分解可能 存在新碳的激发效应, 增加有机碳输人可能刺激土 壤微生物活动而增加土壤有机碳碳库分解释放, 例 如李玲等人 ${ }^{[117]}$ 采用 ${ }^{14} \mathrm{C}$ 标记秸秆研究新碳对农田土 壤有机碳的激发效应(Priming effect), 但稻田土壤有 机碳分解及这种激发效应明显弱于旱地. 农田土壤 有机质积累的生物学稳定可能存在土壤生态机制, 而不能用碳基质与微生物数量与活性的静态关系来 解释. 正如前述, 已有的研究资料还充分显示了农田 土壤有机碳积累与农田生态系统生产力和氮素有效 性提高有关, 因而有机碳积累还通过减少化肥氮素 消耗而间接贡献于温室气体减排 ${ }^{[85]}$. 因此, 农田土 壤固碳有利于降低单位作物生产的温室气体强度, 从而提高农业生产的碳效益.

\section{4 结语与展望}

关于中国土壤碳库计量的研究一直是中国土地 利用与全球变化研究的焦点, 10 多年来估计研究方 法学已经较为成熟, 估计值也已十分接近. 一个薄弱 的方面是表土的碳库及其土地利用历史变化系统研 究较少, 这与我国表土资料不规范有关. 我国关于土 壤有机碳动态的研究中, 农田土壤资料, 特别是表土 耕作层资料丰富, 国土生态地球化学调查表土为 20 $\mathrm{cm}$ 深度, 农业部测土配方施肥中深度也定为 $0 \sim 20$ $\mathrm{cm}$, 但稻田为 $0 \sim 15 \mathrm{~cm}$. 相反, 国外研究中表土深度 一般是 $0 \sim 30 \mathrm{~cm}$. 这制约了表土碳库研究及其国际对 比. 另外, 深层土壤储碳可能对于促进生态系统固碳 和减缓地球表层系统中碳更新速率具有重要意义, 近 5 年多来国际上关于深层土壤固碳研究十分活跃. 但是我国深层有机碳监测资料很少, 这是我国土壤 碳库研究的明显不足.

我国广大的国土面积处于干旱半干旱气候地区,
土壤中广泛分布的无机碳在陆地土壤碳库中占有重 要地位. 特别是无机碳是地球表层系统中更新速率 最低的碳形态, 因而结合有机、无机碳形态的转化而 揭示无机碳的固定作用和碳汇潜力对于我国未来的 地质储存和固定将具有重要的科学价值, 这是今后 研究中值得注意和发展的领域.

研究全球变化中区域、流域土壤碳库动态及其与 土地利用变化和全球气候变化的关系也将是地学-生 态学交叉研究的新领域. 这方面可以借鉴美国等西 方国家地学界正在探索的地球临界带系统 ${ }^{[18]}$ 固碳研 究的理论框架, 结合土壤固碳和岩石风化的地球化 学固碳, 流域系统的碳搬运与堆积的储存探讨区域 或流域土壤固碳容量与赋存状态, 可能为我国地学 界、农业和生物科学界联合研究以流域为基本尺度和 临界带地球表层系统为基本对象的生物地球化学和 生态学固碳与碳汇问题的研究提供理论支撑, 这将 是未来固碳科学研究的重要理论方向.

我国广大地区的生态系统和农业生产的脆弱性 十分明显, 提高农业生产能力和资源利用效率, 改善 生态系统服务功能可能是未来碳科学, 特别是固碳 研究的发展方向。中国高强度土地利用下土壤固碳 的理论容量和技术潜力研究, 土壤固碳的农业与生 态系统生产力及生态服务功能效应研究可能是未来 中国农业土壤固碳研究的重点, 并可能为建立中国 特色土壤固碳理论框架和生产力机理提供研究契机. 不同地区和不同类型生态系统中土壤碳库稳定性及 其温室气体的释放与土地利用变化和气候变化的关 系仍然需要更多实验和就地观测研究.

总之, 我国农业和生态系统土壤碳循环研究必 须顺应国际地球系统科学与全球变化研究的发展趋 势, 需要在研究技术上不断创新. 土壤固碳理论研究 需要吸收采用土壤学、生物学(分子、生物学)和现代 分析技术，从宏观和微观的两种角度、从国家-区域田块的多种空间尺度, 进行多学科、多尺度研究和多 界面研究系统集成, 在人为作用-土壤碳循环-全球变 化相互作用上展现我国土壤碳循环研究特色, 在国 际上占据应有的影响。

\section{参考文献}

1 Intergovernmental Panel on Climate Change. Climate Change 2007: The Physical Science Basis. Working Group I Contribution to the Fourth Report of the Intergovernmental Panel on Climate Change, 2007 
2 Lal R. Soil C sequestration impacts on global climatic change and food security. Science, 2004, 304: 1623-1627

3 方精云, 郭兆迪, 朴世龙, 等. 1981 2000 年中国陆地植被碳汇的估算. 中国科学 D 辑：地球科学, 2007, 37: 804-812

4 张旭辉, 李典友, 潘根兴, 等. 我国湿地土壤资源保护与气候变化问题. 气候变化研究进展, 2008, 4: 202-208

5 方精云, 刘国华, 徐嵩龄. 中国陆地生态系统碳循环及其全球意义. 见: 王庚辰, 温玉璞, 编. 北京: 中国环境科学出版社, 1996. $129-139$

6 潘根兴. 中国土壤有机碳、无机碳库量研究. 科技通报, 1999, 15: 330-332

7 全国土壤普查办公室. 中国土种志(1 6 卷). 北京: 中国农业出版社, 1993, 1994, 1995, 1996

8 王绍强, 周成虎. 中国陆地土壤有机碳库的估算. 地理研究, 1999, 18: 349-355

9 王绍强, 周成虎, 李克让. 中国土壤有机碳库及空间分布特征分析. 地理学报, 2000, 55: 533-544

10 Wu H B, Guo Z T, Peng C H. Land use induced changes of organic carbon storage in soils of China. Glob Change Biol, 2003, 9: 305-315

11 Yang Y H, Mohammat A, Feng J M, et al. Storage, patterns and environmental controls of soil organic carbon in China. Biogeochem, 2007, 84: 131-141

12 Li Z P, Han F X, Su Y, et al. Assessment of soil organic and carbonate carbon storage in China. Geoderma, 2007, 138: 119-126

13 Yu D S, Shi X Z, Wang H J, et al. National scale analysis of soil organic carbon storage in China based on chinese soil taxonomy. Pedosphere, 2007, 17: 11-18

14 Yu D S, Shi X Z, Wang H J, et al. Regional patterns of soil organic carbon stocks in China. J Environ Manag, 2007, 85: 680-689

15 赵生才. 我国农田土壤碳库演变机制及发展趋势—第 236 次香山科学会议侧记. 地球科学进展, 2005, 20: 587-590

16 Pan G, Guo T. Pedogenic carbonates of aridic soils in China and its significance in carbon sequestration in terrestrial systems. In: Lal R, Kimble J M, Eswaran H, et al, eds. Global Climate Change and Pedogenic Carbonates. Boca Raton: CRC/Lewis Publishers, 1999. 135-148 Agric, Ecosyst Environ, 2009, 129: 413-421

\section{0: $301-304$}

26 Rickman R W, Douglas J C L, Albrecht S L, et al. CQESTR: A model to estimate carbon sequestration in agricultural soils. J Soil Water Conser, 2001, 56: 237-241

27 Lal R. Soil management and restoration for C sequestration to mitigate the accelerated greenhouse effect. Prog Environ Sci, 1999, 1: $307-326$

28 Intergovernmental Panel on Climate Change. Climate Change 1995: Impact Adaptations and Mitigation of Climate Change Scientific Technical Analysis. Cambridge: Cambridge University Press, 1996

29 Lindert P H, Lu I, Wu W. Trends in the soil chemistry of South China since the 1930s. Soil Sci, 1996, 161: 329-342

30 李长生. 土壤碳库量之减少, 中国农业之隐患: 中美农业生态系统碳循环比较研究. 第四纪研究, 2000, 20: 345-350

31 Song G H, Li L Q, Pan G. Topsoil organic carbon storage of China and its loss by cultivation. Biogeochem, 2005, 74: 47-62

32 任京辰, 张平究, 潘根兴, 等. 岩溶土壤的生态地球化学特征及其指示意义. 地球科学进展, 2006, 21: 504-512

33 李恋卿, 潘根兴, 张平究, 等. 植被恢复对退化红壤表层土壤颗粒中有机碳和 $\mathrm{Pb} 、 \mathrm{Cd}$ 分布的影响. 生态学报, 2001, 21: 1769-1774

34 李长安. 中国湿地环境现状与保护对策. 中国水利, 2004, 3: 24-26

35 侯伟, 匡文慧, 张树文, 等. 近 50 年来三江平原北部土地利用/土地覆被变化及生态效应分析. 生态环境, 2006, 15: 752-756

36 郝庆菊, 王跃思, 宋长春, 等. 垦殖对沼泽湿地 $\mathrm{CH}_{4}$ 和 $\mathrm{N}_{2} \mathrm{O}$ 排放的影响. 生态学报, 2007, 27: 3417-3426

37 王树起, 韩晓增, 乔云发, 等. 不同土地利用方式对三江平原湿地土壤酶分布特征及相关肥力因子的影响. 水土保持学报, 2007, 21: 150-192

38 陆琦, 马克明, 张洁瑜, 等. 三江平原退化湿地和农田土壤养分的比较研究. 生态与农村环境学报, 2007, 23: 23-28

39 刘子刚, 张坤民. 黑龙江三江平原湿地土壤碳储量变化. 清华大学学报(自然科学版), 2005, 45: 788-791

40 刘燕华. 应对国际 $\mathrm{CO}_{2}$ 减排压力途径及我国减排 $\mathrm{CO}_{2}$ 潜力分析. 见: IGBP-CNC2007 年会会议集. 2008

41 Batjes N H. Carbon and nitrogen in the soils of the world. Eur J Soil Sci, 1996, 47: 151-163

42 Smith P. Carbon sequestration in croplands: The potential in Europe and the global context. Eur Agron, 2004, 20: 229-236 
43 Pan G X, Li L Q, Wu L S, et al. Storage and sequestration potential of topsoil organic carbon in China's paddy soils. Glob Chang Biol, 2003, 10: 79-92

44 许信旺, 潘根兴, 汪艳林, 等. 中国农田耕层土壤有机碳变化特征及控制因素. 地理研究, 2009, 28: 601-612

45 侯鹏程, 徐向东, 潘根兴. 不同土地利用方式对农田表土有机碳库的影响一以太湖地区吴江市为例. 南京农业大学学报, 2007, 30: $68-72$

46 李志鹏, 潘根兴, 张旭辉. 改种玉米连续 3 年后稻田土壤有机碳分布和 ${ }^{13} \mathrm{C}$ 自然丰度变化. 土壤学报, 2007, 44: $244-251$

47 Tan S, Heerink N, Kruseman G, et al. Land fragmentation and its driving forces in China. Land Use Policy, 2006, 23: 272-285

48 Rahman S, Rahman M. Impact of land fragmentation and resource ownership on productivity and efficiency: The case of rice producers in Bangladesh. Land Use Policy, 2009, 26: 95-103

49 Tan S, Heerink N, Kruseman G, et al. Do fragmented landholdings have higher production costs? Evidence from rice farmers in Northeastern Jiangxi Province, P.R. China. Econ Rev, 2008, 19: 347-358

50 De Costa W A, Sangakkara U R. Agronomic regeneration of soil fertility in tropical Asian smallholder uplands for sustainable food production. J Agric Sci, 2006, 144: 111-133

51 Feng S Y, Tan S H, Zhang A F, et al. Effect of household land management on cropland topsoil organic carbon storage at plot scale in a red earth soil area of South China. J Agric Sci, 2011, doi: 10.1017/S0021859611000323

52 Food \& Agriculture Organization (FAO). Soil carbon sequestration for improved land management. World Soil Resources Reports. 2001

53 张琪, 李恋卿, 潘根兴, 等. 近 20 年来宜兴市域水稻土有机碳动态及其驱动因素. 第四纪研究, 2004, 24: 236-242

54 张琪. 近 20 年来水稻土有机碳变化一县级和村级尺度研究. 硕士学位论文. 南京: 南京农业大学, 2004. 36-44

55 徐艳, 张凤荣, 汪景宽. 20 年来我国潮土区与黑土区土壤有机质变化的对比研究. 土壤通报, 2004, 35: 102-105

56 王伯仁, 徐明岗, 文石林. 长期不同施肥对旱地红壤性质和作物生长的影响. 水土保持学报, 2005, 19: 97-100

57 陈安磊, 王凯荣, 谢小立, 等. 不同施肥模式下稻田土壤微生物生物量磷对土壤有机碳和磷素变化的响应. 应用生态学报, 2007, 18: 2733-2738

58 周萍, 张旭辉, 潘根兴. 长期不同施肥对太湖地区黄泥土总有机碳及颗粒态有机碳含量及深度分布的影响. 植物营养与肥料学报, 2006, 12: 765-771

59 Huang X X, Gao M, Wei C F, et al. Tillage effect on organic carbon in a purple paddy soil. Pedosphere, 2006, 16: 660-667

60 孟磊, 蔡祖聪, 丁维新. 长期施肥对土壤碳储量和作物固定碳的影响. 土壤学报, 2005, 42: 769-776

61 Xie Z B, Zhu J G, Liu G, et al. Soil organic carbon stocks in China and changes from 1980s to 2000s. Glob Chang Biol, 2007, 13: 1989-2007

62 Liu J Y, Wang S, Chen J M, et al. Storages of soil organic carbon and nitrogen and land use changes in China 1990-2000. Acta Geogr Sin, 2004, 59: 483-496

63 吴乐知, 蔡祖聪. 基于长期实验资料对中国农田表土有机碳含量变化的估算. 生态环境, 2007, 16: 1768-1774

64 黄耀, 孙文娟. 近 20 年来我国耕地土壤有机碳含量的变化趋势. 科学通报, 2006, 51: 753-763

65 Sun W J, Huang Y, Zhang W, et al. Carbon sequestration and its potential in agricultural soils of China. Glob Biogeochem Cycles, 2010, 24: 1302-1307

66 Pan G X, Xu X W, Smith P, et al. An increase in topsoil SOC stock of China's croplands between 1985 and 2006 revealed by soil monitoring. Agric Ecosyst Environ, 2010, 136: 133-138

67 李忠佩. 低丘红壤有机碳库的密度及分异. 土壤, 2004, 36: 292-297

68 许信旺. 不同地理尺度下农田土壤有机碳分布与变化. 博士学位论文. 南京: 南京农业大学, 2008. 33-45

69 王成己，潘根兴，田有国. 保护性耕作下农田表土有机碳含量变化特征分析一基于中国农业生态系统长期试验资料. 农业环境科 学学报, 2009, 28: 2464-2475

70 王成已. 施肥和耕作长期试验下农田土壤有机碳及作物生产力变化的统计研究. 博士学位论文. 南京: 南京农业大学, 2010. 55-61

71 Sperow M, Eve M, Paustian K. Potential soil C sequestration on US agricultural soils. Clim Change, 2003, 57: 319-339

72 Freibauer A, Rounsevellb M D A, Smith P, et al. Carbon sequestration in the agricultural soils of Europe. Geoderma, 2004, 122: 1-23

73 Liao Q L, Zhang X H, Li Z P, et al. Increase in soil organic carbon stock over the last two decades in China's Jiangsu Province. Glob Chang Biol, 2009, 15: 861-875

74 Smith P, Martino D, Cai Z C, et al. Greenhouse gas mitigation in agriculture. Philosoph Trans Roy Soc, 2008, 363: 789-813

75 郑聚锋, 张旭辉, 潘根兴, 等. 水稻土基底呼吸与 $\mathrm{CO}_{2}$ 排放强度的日动态及长期不同施肥下的变化. 植物营养与肥料学报, 2006,12 : $485-494$

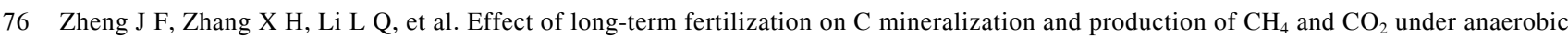
incubation from bulk samples and particle size fractions of a typical paddy soil. Agric Ecosys Environ, 2007, 120: 129-138

77 李洁静, 潘根兴, 张旭辉, 等. 太湖地区长期施肥条件下水稻-油菜轮作生态系统净碳汇效应及收益评. 应用生态学报, 2009 , 20 : $1664-1670$ 
78 李洁静, 潘根兴, 李恋卿, 等. 红壤丘陵双季稻稻田农田生态系统不同施肥下碳汇效应及收益评估. 农业环境科学学报, 2009, 28: $2520-2525$

79 向昌国, 张平究, 潘根兴, 等. 长期不同施肥下太湖地区黄泥土虹蚓的多样性、蛋白质含量与氨基酸组成的变化. 生态学报, 2006, 26: $1667-1674$

80 张平究, 李恋卿, 潘根兴, 等. 长期不同施肥下太湖地区黄泥土表土微生物碳氮量及基因多样性变化. 生态学报, 24: 2819-2824

81 郑聚锋, 潘根兴, 李恋卿. 长期不同施肥下水稻土 $\mathrm{CH}_{4}$ 氧化能力及甲烷氧化菌多样性的变化. 生态学报, 2008, 28: 4864-4872

82 冯伟, 潘根兴, 强胜, 等. 长期不同施肥方式对稻油轮作田土壤杂草种子库多样性的影响. 生物多样性, 2006, 14: 461-469

83 韩晓君, 潘根兴, 李恋卿. 长期不同施肥处理下有机质含量变化对土壤中多环芳烃降解的影响一以太湖地区黄泥土长期试验为 例. 农业环境科学学报, 2009, 28: 2533-2539

84 Pan G, Smith P, Pan W. The role of soil organic matter in maintaining the productivity and yield stability of cereals in China. Agric Ecosyst Environ, 2009, 129: 344-348

85 Pan G, Zhou P, Li Z, et al. Combined inorganic/organic fertilization enhances $\mathrm{N}$ efficiency and increases rice productivity through organic carbon accumulation in a rice paddy from the Tai Lake region, China. Agric Ecosyst Environ, 2009, 131: 274-280

86 潘根兴, 赵其国. 我田土壤碳库演变研究：全球变化和国家粮食安全. 地球科学进展, 2005, 20: 384-392

87 Pan G. Stock, dynamics of soil organic carbon of china and the role in climate change mitigation. Adv Clim Change Res, 2009, 5(Supp 1): $11-18$

88 农业部, 国家发改委. 保护性耕作工程建设规划. 2009

89 农业部办公厅，财政部办公厅. 2010 年全国测土配方施肥补贴项目实施指导意见. 2010

90 柳铮铮, 曾从盛, 钟春棋, 等. 酸沉降对泥炭地甲烷排放和碳循环的影响. 生态学杂志, 2008, 27: 1799-1805

91 Zhang X H, Li L Q, Pan G X. Topsoil organic carbon mineralization and $\mathrm{CO}_{2}$ evolution of three paddy soils from South China and the temperature dependence. J Environ Sci, 2007, 19: 319-326

92 Grandy A S, Robertson G P. Land use intensity effects on soil C accumulation rates and mechanisms. Ecosystems, 2007, 10: 59-74

93 潘根兴, 周萍, 李恋卿, 等. 固碳土壤学的核心科学问题与研究进展. 土壤学报, 2007, 44: 327-337

94 Leinweber P, Jandl G, Baum C, et al. Stability, composition of soil organic matter control respiration and soil enzyme activities. Soil Biol Biochem, 2008, 40: 1496-1505

95 Kemmitt S J, Lanyon C V, Waite I S, et al. Mineralization of native soil organic matter is not regulated by the size, activity or composition of the soil microbial biomass-A new perspective. Soil Biol Biochem, 2008, 40: 61-73

96 Fang C, Smith P, Moncrieff J B, et al. Similar response of labile and resistant soil organic matter pools to changes in temperature. Nature, 2005, 433: 57-59

97 Vanhala P, Karhu K, Tuomi M, et al. Old soil carbon is more temperature sensitive than the young in an agricultural field. Soil Biol Biochem, 2007, 39: 2967-2970

98 Rinna J, Warning B, Meyers P A, et al. Combined organic and inorganic geochemical reconstruction of paleo-depositional conditions of a Pliocene sapropel from the eastern Mediterranean Sea. Geochim Cosmochim Acta, 2007, 66: 1969-1986

99 周萍, 潘根兴, Piccolo A, 等. 南方典型水稻土长期试验下有机碳积累机制研究. IV 颗粒有机质热裂解-气相-质谱法分子结构初 步表征. 土壤学报, 2011, 48: 112-124

100 张逸飞, 钟文辉, 李忠佩, 等. 长期不同施肥处理对红壤水稻土酶活性及微生物群落功能多样性的影响. 生态与农村环境学报, 2006, 22: 39-44

101 郑聚锋. 长期不同施肥条件下南方典型性水稻土有机碳矿化作用与 $\mathrm{CO}_{2} 、 \mathrm{CH}_{4}$ 产生研究. 博士学位论文. 南京: 南京农业大学, 2007. 46-51

102 Williams M A, Myrolda D D, Biolltomley P J. Carbon flow from ${ }^{13} \mathrm{C}$-labelled clover and ryegrass residues into a residue-associated microbial community under field conditions. Soil Biol Biochem, 2007, 39: 819-822

103 Ström L, Christensen T R. Below ground carbon turnover and greenhouse gas exchanges in a sub-arctic wetland. Soil Biol Biochem, 2007, 39: $1689-1698$

104 Bader N E, Cheng W. Rhizosphere effect of Populus fremontii roots masks the temperature sensitivity of soil organic carbon respiration. Soil Biol Biochem, 2007, 39: 600-606

105 Pendall E, King J Y. Soil organic matter dynamics in grassland soils under elevated $\mathrm{CO}_{2}$ : Insights from long-term incubations and stable isotopes. Soil Biol Biochem, 2007, 39: 2628-2639

106 宋长春, 王毅勇, 王跃思, 等. 沼泽叚殖前后土壤呼吸与 $\mathrm{CH}_{4}$ 通量变化. 土壤通报, 2005, 36: 45-49

107 郑聚锋, 潘根兴, 吴新民, 等. 淡水湿地土壤呼吸动态及有机碳稳定性研究一以安徽省升金湖湿地为例. 湿地科学, 2011, 9: 132-139

108 迟传德，许信旺，吴新民，等. 安徽省升金湖湿地土壤有机碳储存及分布. 地球与环境, 2006, 34: 59-64

109 林凡, 李典友, 潘根兴, 等. 皖江自然湿地土壤碳密度及其开乍为农田后的变化. 湿地科学, 2008, 6: 192-197 
110 Sun W J, Huang Y, Chen S T, et al. Dependence of wheat and rice respiration on tissue nitrogen and the corresponding net carbon fixation efficiency under different rates of nitrogen application. Adv Atmos Sci, 2007, 24: 55-64

111 尹云锋, 蔡祖聪. 不同施肥措施对潮土有机碳平衡及固碳潜力的影响. 土壤, 2006, 38: 745-749

112 Liu D W, Liu X Y, Liu Y Z, et al. SOC accumulation in paddy soils under long-term agro-ecosystem experiments from South China. VI. Changes in microbial community structure and respiratory activity. Biogeosci Discuss, 2011, 8: 1-26

113 Zou J W, Lu Y Y, Huang Y. Estimates of synthetic fertilizer N-induced direct nitrous oxide emission from Chinese croplands during 1980-2000. Environ Pollut, 2010, 158: 631-635

114 李洁静, 潘根兴, 李恋卿, 等. 太湖地区长期施肥条件下水稻 2 油菜轮作生态系统净碳汇效应及收益评估. 应用生态学报, 2009 , 20: $1664-1670$

115 李洁静, 潘根兴, 李恋卿, 等. 红壤丘陵双季稻稻田农田生态系统不同施肥下碳汇效应及收益评估. 农业环境科学学报, 2009, 28: 2520-2525

116 彭华, 纪雄辉, 刘昭兵, 等. 洞庭湖地区长期施肥条件下双季稻田生态系统净碳汇效应及收益评估. 农业环境科学学报, 2009, 28: 2526-2532

117 李玲, 肖和艾, 吴金水. 红壤旱地和稻田土壤中有机底物的分解与转化研究. 土壤学报, 2007, 44: 669-674

118 Amundson R, Richter D D. Humphreys G, et al. Coupling between biota and earth materials in the critical zone. Elements, 2007, 3: $327-332$ 